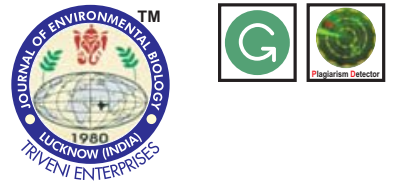

\title{
Assessment of photosynthetically active radiation, photosynthetic rate, biomass and yield of two maize varieties under varied planting dates and nitrogen application
}

Authors Info

A.P. Ghosh, A. Dass*, P. Krishnan, R. Kaur and K.S. Rana

Division of Agronomy, Division of Agricultural Physics, ICAR-Indian Agricultural Research Institute, New Delhi-110 012, India

${ }^{*}$ Corresponding Author Email : anchal_iari@rediffmail.com

Key words

Maize varieties,

Nitrogen application,

Photosynthetic rate,

Photosynthetically active radiation,

Planting dates

Publication Info

Paper received : 13.12 .2015

Revised received : 03.05.2016

Re-revised received : 04.10 .2016

Accepted:01.12.2016

\section{Abstract}

Aim : Genotypes, environment and nutritional management greatly influence physiological and agronomic performance of maize (Zea mays L.), one of the important staple food crops. Among the plant nutrients, nitrogen is the most important nutrient that governs the maize growth and its productivity, but applied nitrogen fertilizer is subjected to various losses. These facts necessitate the determination of suitable planting time and precise $\mathrm{N}$-application schedule for maize. Hence, the current field experiment was conducted to assess the photosynthetically active radiation (PAR) interception, net photosynthetic rate (NPR) and production potential of maize varieties under variable growing environments and Soil Plant Analysis Development (SPAD) meter (also known as chlorophyll meter) guided $\mathrm{N}$-application rates.

Methodology : The experiment consisted of twenty-four treatments comprising two-maize varieties, Pusa Extra Early Hybrid Makka 5 (PEEHM 5) and Pusa Composite 3 (PC 3), three-planting dates, July 9, July 24 and August 7 and four-nitrogen ( $\mathrm{N}$ ) application rates, no- $\mathrm{N}$ (control), $30 \mathrm{~kg} \mathrm{~N} \mathrm{ha}^{-1}$ as basal $+30 \mathrm{~kg} \mathrm{~N}^{-1} \mathrm{a}^{-1}$ topdressed as and when average SPAD value dropped to $\leq 37.5$ (CMB), $30 \mathrm{~kg} \mathrm{~N}^{-1}{ }^{-1}$ as basal $+30 \mathrm{~kg} \mathrm{~N}^{-1}$ top-dressed at knee-high, pre-tasseling and silking stages when average SPAD value dropped to $\leq 37.5$ and Soil Test Crop Response based N-application (STCRB). The experiment was laid-out in a split-plot design assigning six-combinations of varieties and planting dates in main-plots and four-nitrogen application rates in split-plots. All the treatments were replicated thrice.

Results : Hybrid PEEHM 5 recorded $5.23 \%$ higher grain yield, higher total biomass and net photosynthetic rate at early stages, while PC 3 showed 4.53 and $2.57 \%$ higher PAR at knee-high and tasseling stages, respectively. Among $\mathrm{N}$-management practices, CMB N-application improved grain yield by $9.25 \%$ and saved $10 \mathrm{~kg} \mathrm{~N}^{-1} a^{-1}$ over STCRB N. Early planting on July 9 provided yield advantage of $5 \%$ over July 24 and $20 \%$ over late planting (August 7 ). Variety $\times \mathrm{N}$-rate interaction revealed highest NPR in PC 3 under CMB N application.

Interpretation: The results of the investigation clearly demonstrated that planting of maize should not be delayed beyond second week of July in North Indian plains and chlorophyll meter reading i.e., average SPAD value $\leq 37.5$ of top-most fully expanded leaf, may be used in scheduling $\mathrm{N}$-top dressing to meet out inseason $\mathrm{N}$-requirement, for achieving higher growth and productivity of maize crop.

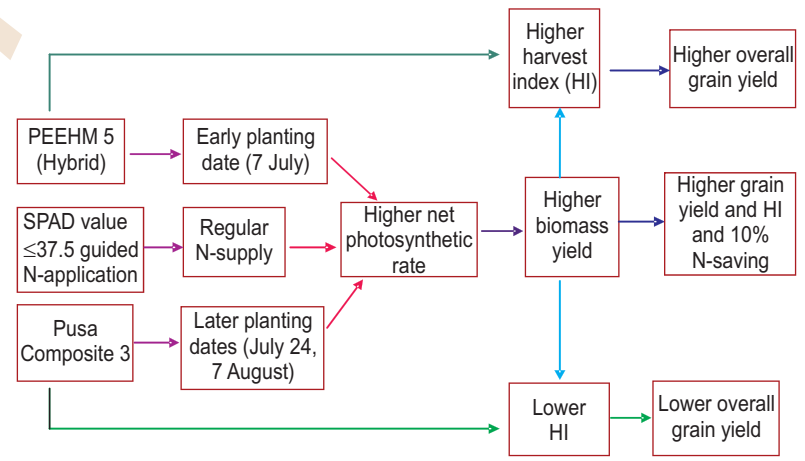




\section{Introduction}

Maize (Zea mays) is an important food crop cultivated over varying climatic conditions with large yield variations worldwide occupying 177 million hectare ( $\mathrm{m}$ ha) land, producing 989 million tonne $(\mathrm{m} \mathrm{t})$ grain with an average productivity of $5.5 \mathrm{t} \mathrm{ha}^{-1}$. In India, the crop is cultivated on $9.4 \mathrm{~m}$ ha land with a total production of $22.97 \mathrm{~m}$ t at a low average productivity of $2.56 \mathrm{tha}^{-1}$ (Economic Survey, 2014-15). Planting dates govern the climatic conditions that would be available to the crop, and thereby exert considerable influence on the physiological parameters like photosynthesis, growth and yield potential of maize. Several workers have shown that planting of maize before or after optimum date causes significant reduction in growth and development and alterations in biomass production, finally leading to yield loss. Thus, determining optimal planting time for potential maize cultivars is important for enhancing maize yield.

A decrease in soil fertility and inefficient use of $\mathrm{N}$ fertilizers are the other important reasons for low yield of maize. Nitrogen is the most important plant nutrient that determines maize yield (Muurinen and Peltonen-Sainio, 2006), as it is an important component of chlorophyll, protein and nucleic acid influencing photosynthesis and making up 1-4\% of dry matter of plants (FAO, 2000). However, a large requirement of nitrogen for maize is a major concern to the producers because $\mathrm{N}$-fertilizers are often applied in bulk quantities at one time and not as per plant demand, thus not taken up by plant. A major chunk of applied nitrogen is lost due to leaching and volatilization causing ground water contamination, global warming decreased soil fertility, reduced $\mathrm{N}$-use efficiency to $40-50 \%$, low biomass and yield and increased cultivation cost. Precision nitrogen management using chlorophyll meter, also known as Soil Plant Analysis Development (SPAD) meter, offers a solution to these problems by supplying nitrogen when plant requires it (Dass et al., 2015). Values obtained from the SPAD meter are highly correlated with the nitrogen status of maize (Fox et al., 2001) because chlorophyll content depends on nitrogen supply. Dass et al. (2014) found that applying nitrogen based on SPAD value $\leq 37.5$ resulted in the highest maize yield $\left(5.2\right.$ tha $\left.^{-1}\right)$, which was significantly higher than soil test based and SPAD value $\leq 35$ based $\mathrm{N}$ applications, and also saved $30-45 \mathrm{~kg} \mathrm{Nha}^{-1}$.

Response of maize to nitrogen application may differ in varieties and growing environments. Thus, the present study was carried out to assess the effect of planting dates and nitrogen application on net intercepted photosynthetically active radiation (PAR), net phoyosynthetic rate (NPR), biomass and yield of two maize varieties.

\section{Materials and Methods}

A field experiment was conducted at ICAR- Indian Agricultural Research Institute, New Delhi during rainy season of
2014-15. The climate of New Delhi is of sub-tropical and semi-arid type with hot and dry summer and cold winter and falls under the agro-climatic zone 'Trans-Gangetic plains'. The data on weather conditions during experimental period were obtained from the Aclass Agro-meteorological Observatory, Division of Agricultural Physics, IARI, New Delhi, 2014. During the crop period, mean weekly maximum temperature was $34.2^{\circ} \mathrm{C}$, while the mean minimum temperature was $22.8^{\circ} \mathrm{C}$. Mean weekly maximum and minimum relative humidity, sunshine hours/day and evaporation during the growing season were $84.8 \%, 53.2 \%, 5.6$ and 6 $\mathrm{mm} /$ day, respectively. Crop season received rainfall of $564 \mathrm{~mm}$ with a weekly average of $313 \mathrm{~mm}$ (Fig. 1). Soil of the experimental field was sandy loam in texture, medium in organic $\mathrm{C}(0.58 \%)$, low in available nitrogen (224 kg ha ${ }^{-1}$ ) and medium in available phosphorus (18.7 kg ha-1) and potassium (262 kg ha-1) contents. Soil reaction was neutral ( $\mathrm{pH} 7.4$ )

The experiment was laid-out in a split-plot design. There were 24 treatment combinations of 2-maize varieties, Hybrid PEEHM 5, Composite PC 3, 3-planting dates (July 9 , July 24, August 7) in the main-plots, and 4-N rates, control (no-N), chlorophyll meter based $\mathrm{N}$ application up to silking (CMB): $30 \mathrm{~kg}$ $\mathrm{ha}^{-1}$ basal $+30 \mathrm{~kg} \mathrm{ha}^{-1}$ top-dressed at SPAD value $\leq 37.5$ (Total quantity of $\mathrm{N}: 150 \mathrm{~kg} \mathrm{ha}^{-1}$ ), chlorophyll meter based $\mathrm{N}$ application stage-wise (CMBSW): $30 \mathrm{~kg} \mathrm{ha}^{-1}$ basal $+30 \mathrm{~kg} \mathrm{~N} \mathrm{ha}^{-1}$ top-dressed during knee high, pre-tasseling and silking stages at SPAD value $\leq 37.5$ (Total quantity of $\mathrm{N}: 120 \mathrm{~kg} \mathrm{ha}^{-1}$ ), and soil test crop response based (STCRB) application (Total quantity of N:160 kg $\mathrm{ha}^{-1}$ ), in sub-plots. Fertilizer $\mathrm{N}$ recommendation for maize for a targeted yield of $4.2 \mathrm{tha}^{-1}$ was calculated using STCR equation at the beginning of the experiment and computed values were rounded off to $160 \mathrm{~kg} \mathrm{~N} \mathrm{ha}^{-1} . \mathrm{F}_{\mathrm{N}}=6.61 \mathrm{~T}-0.52 \mathrm{SN}$ (where, $\mathrm{T}$ is yield target; $\mathrm{SN}$ is soil $\mathrm{N}$ status before sowing). All the treatments were replicated thrice constituting seventy-two experimental plots of size $4.8 \times 3 \mathrm{~m}$ each. Maize was planted in rows $60 \mathrm{~cm}$ apart using $20 \mathrm{~kg}$ seed per ha. Plant to plant interval was kept as $20 \mathrm{~cm}$. Phosphorus, potassium and zinc were uniformly applied @ $60 \mathrm{~kg} \mathrm{P}_{2} \mathrm{O}_{5} 40 \mathrm{~kg} \mathrm{~K}_{2} \mathrm{O}$ and $25 \mathrm{~kg} \mathrm{ZnSO}_{4}$ per ha, respectively. In STCRB, fertilizer nitrogen was applied in three equal splits (1 basal + 2 top- dressing), whereas in CMB and CMBSW, nitrogen was applied as indicated in the treatments. All the other recommended practices were followed to raise healthy experimental crop.

Net photosynthetic rate (NPR) was measured on a bright sunny day between $10 \mathrm{am}$ to $12 \mathrm{pm}$ for the top-most fully opened leaf at knee-high and tasseling stages using infrared gas analyzer (LI-COR, model LI-6400XT Portable Photosynthesis System) (Anonymous, 2011). The PAR was determined using canopy analyser LP-80 AccuPAR and net intercepted PAR was obtained by subtracting value of penetrated PAR at bottom from incident PAR at the top of canopy (Anonymous, 2015). To determine dry matter accumulation (DMA) in different plant parts at different growth stages, five plants from the sampling rows i.e. second row 
from each plot border were selected and uprooted with roots intact digging hole with spade and core bar and their root, leaf and stem portions were separated and air dried for four days, and thereafter these were dried in a hot-air oven at $80^{\circ} \mathrm{C}$ till constant weights were obtained (Tollenaar and Migus, 1984). Grain and straw yields were determined by harvesting crop (cobs and stalks) from the net plots, leaving aside two border rows from both sides of the plot and half meter on opposite directions of the plots. All data were subjected to 'Analyses of variance' technique for a split-plot design. The least significant difference (LSD) values at $5 \%$ level of significance were computed for comparing the differences among treatment means (Gomez and Gomez, 1984).

\section{Results and Discussion}

At knee-high stage, PEEHM 5 recorded $12.6 \%$ higher NPR compared to PC 3; however at tasseling stage, varieties did not differ significantly (Fig. 2, 3). Photosynthetic efficiency is a function of foliage characteristics like leaf surface using solar energy and ability to close or open stomata (Almodares et al., 2013) which seems to differ with varieties due to their inherent genetic make-up. Faizan et al. (2012) also reported significant differences among varieties for total chlorophyll content, biomass and yield. Composite variety PC 3 showed 4.74 and 2.64\% greater PAR interception at knee high and tasseling stage, respectively, than PEEHM 5 (Fig. 4). These findings are consistent with the findings of Singh et al. (2014) who reported that PAR interception exhibited significant variation among genotypes. Due to varied photosynthetic ability, translocation of photosynthates and intercepted PAR, maize varieties also showed significant influence on biomass production, grain and straw yields and harvest index. Hybrid PEEHM 5 accumulated significantly greater amount of DMA in all plant parts, such as leaf, stem and root compared to PC 3 at seedling and knee-high stages and was $5.23 \%$ higher grain yielder than PC 3, while PC 3 showed significantly higher DMA at tasseling stage and was $11.6 \%$ higher straw yielder than PEEHM 5. At maturity, the DMA in stem was marginally higher and leaf DMA was significantly higher in PC 3 than PEEHM 5 (Table 1). Harvest index was significantly higher in the PEEHM 5. Enujeke (2013) also reported similar differential performances of maize varieties.

Growth and yield performance of both maize varieties was different when planted on different planting dates. With regard to NPR at knee-high stage, PEEHM 5 planted on July 9 and July 24 was significantly superior to PC 3 planted on the same dates, but in case of August 7 planting, PC 3 was better (Fig. 2). At all growth stages, August 7 planting in PC 3 resulted in significantly higher intercepted PAR than PEEHM 5 planted on August 7 because of higher biomass production (particularly at later growth stages) which indicated genetic stability and superiority of PC 3 under delayed planting condition than PEEHM 5 (Fig. 4).

Hybrid PEEHM 5 produced 5.06, 4.85 and 3.95 t/ha and PC 3 produced $4.69,4.32$ and 4.16 t ha $^{-1}$ grain yield under July 9 , July 24 and August 7 planting, respectively. These results

Table 1 : Effect of varieties, planting dates and chlorophyll meter based $\mathrm{N}$ application on dry matter partitioning in different plant parts and productivity of maize

\begin{tabular}{|c|c|c|c|c|c|c|c|c|c|c|c|c|c|c|c|}
\hline \multirow[t]{3}{*}{ Treatments } & \multicolumn{12}{|c|}{ Dry matter accumulation (g plant ${ }^{-1}$ ) } & \multirow{3}{*}{$\begin{array}{l}\text { Grain } \\
\text { yield } \\
\left.\text { (tha }{ }^{-1}\right)\end{array}$} & \multirow{3}{*}{$\begin{array}{l}\text { Straw } \\
\text { yield } \\
\left.\text { (tha } a^{-1}\right)\end{array}$} & \multirow{3}{*}{$\begin{array}{l}\text { Harvest } \\
\text { index }\end{array}$} \\
\hline & \multicolumn{3}{|c|}{ Seedling stage } & \multicolumn{3}{|c|}{ Knee-high stage } & \multicolumn{3}{|c|}{ Tasseling stage } & \multicolumn{3}{|c|}{ Maturity stage } & & & \\
\hline & Leaf & Stem & Root & Leaf & Stem & Root & Leaf & Stem & Root & Leaf & Stem & Cob & & & \\
\hline \multicolumn{16}{|l|}{ Varieties } \\
\hline PEEHM 5 & 0.70 & 1.53 & 0.25 & 5.8 & 12.5 & 3.2 & 27.4 & 61.9 & 27.0 & 28.0 & 62.5 & 85.5 & 4.62 & 8.37 & 0.35 \\
\hline $\begin{array}{l}\text { Pusa } \\
\text { Composite } 3\end{array}$ & 0.62 & 1.48 & 0.22 & 4.9 & 10.7 & 3.0 & 36.9 & 66.1 & 28.5 & 31.7 & 63.5 & 82.7 & 4.39 & 9.34 & 0.32 \\
\hline $\begin{array}{l}\mathrm{CD}(\mathrm{P}=0.05) \\
\text { Planting dates }\end{array}$ & 0.02 & 0.05 & 0.01 & 0.29 & 0.66 & 0.08 & 1.79 & 3.14 & 36 & 1.58 & 2.44 & 1.50 & 0.213 & 0.437 & 0.013 \\
\hline July 9 & 0.70 & 1.56 & 0.24 & 5.5 & 12.7 & 3.2 & 30.2 & 68.3 & 29.6 & 29.6 & 61.2 & 92.2 & 4.87 & 9.45 & 0.34 \\
\hline July 24 & 0.67 & 1.54 & 0.24 & 5.6 & 11.8 & 3.2 & 28.7 & 64.9 & 28.1 & 30.3 & 64.9 & 83.8 & 4.58 & 8.96 & 0.34 \\
\hline August 7 & 0.61 & 1.40 & 0.22 & 4.9 & 10.2 & 3.0 & 37.5 & 58.8 & 25.5 & 29.5 & 62.8 & 76.2 & 4.06 & 8.15 & 0.33 \\
\hline$C D(P=0.05)$ & 0.03 & 0.06 & 0.01 & 0.35 & 0.81 & 0.09 & 2.20 & 3.85 & 1.67 & NS & 2.98 & 1.90 & 0.261 & 0.536 & NS \\
\hline \multicolumn{16}{|c|}{ Nitrogen management } \\
\hline Control & 0.58 & 1.34 & 0.20 & 3.9 & 10.2 & 2.7 & 22.2 & 44.8 & 19.4 & 27.6 & 60.0 & 57.7 & 3.03 & 6.19 & 0.33 \\
\hline CMB & 0.67 & 1.54 & 0.24 & 6.3 & 12.4 & 3.4 & 37.4 & 74.2 & 32.2 & 33.7 & 68.6 & 99.8 & 5.31 & 10.27 & 0.34 \\
\hline CMBSW & 0.67 & 1.54 & 0.24 & 5.5 & 11.6 & 3.2 & 34.2 & 68.1 & 29.5 & 28.3 & 61.8 & 88.8 & 4.82 & 9.42 & 0.34 \\
\hline STCRB & 0.72 & 1.58 & 0.26 & 5.6 & 12.1 & 3.2 & 34.8 & 68.9 & 29.8 & 29.4 & 61.6 & 90.0 & 4.86 & 9.54 & 0.34 \\
\hline $\mathrm{CD}(\mathrm{P}=0.05)$ & 0.05 & 0.07 & 0.02 & 0.20 & 0.56 & 0.15 & 1.44 & 2.96 & 1.28 & 2.32 & 2.33 & 3.60 & 0.213 & 0.412 & NS \\
\hline
\end{tabular}

CMB: Chlorophyll meter based $\mathrm{N}$ application up to silking i.e. $30 \mathrm{~kg} \mathrm{ha}^{-1} \mathrm{~N}$ basal $+30 \mathrm{~kg} \mathrm{ha}^{-1} \mathrm{~N}$ top-dressed each time leaf SPAD value falls to $\leq 37.5$; CMBSW: Chlorophyll meter based N application stage-wise i.e. $30 \mathrm{~kg} \mathrm{ha}^{-1} \mathrm{~N}$ basal $+30 \mathrm{~kg} \mathrm{ha}^{-1} \mathrm{~N}$ top-dressed each at knee high, pre-tasseling and silking stages, when SPAD value falls to $\leq 37.5$; STCRB: Soil test crop response based N application 


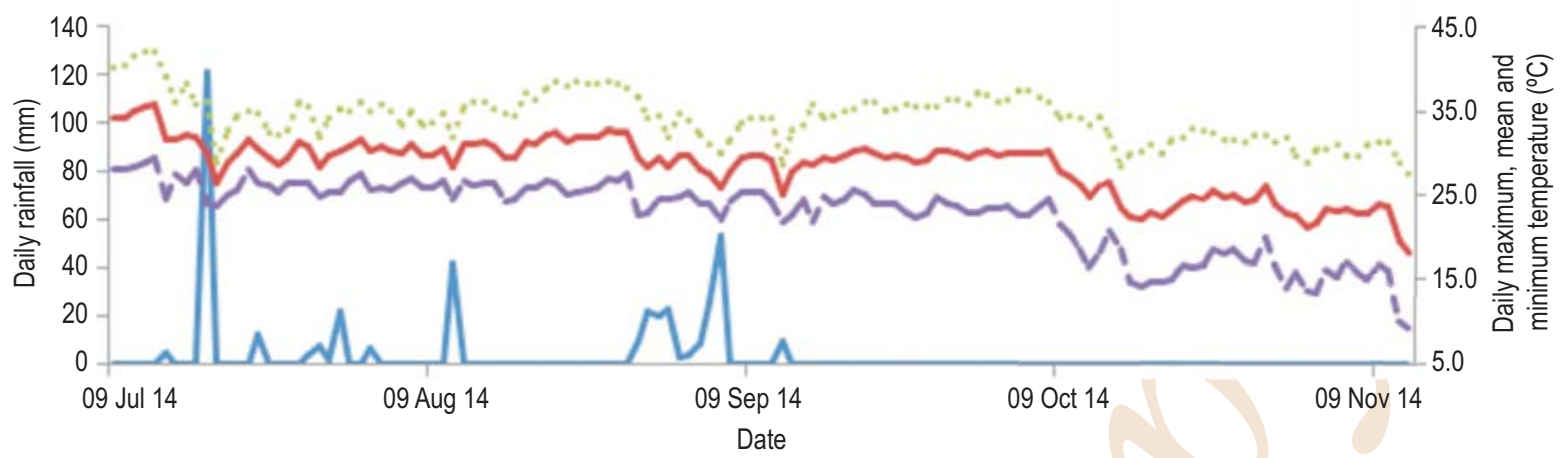

Fig. 1 : Daily rainfall and mean daily temperature during rainy season maize crop period of 2014-15

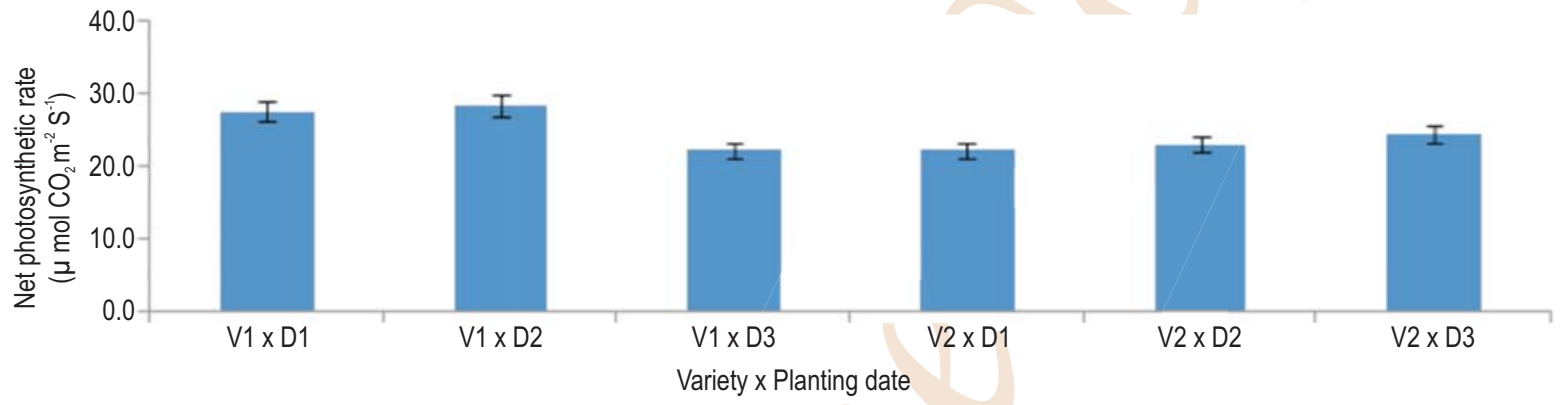

Fig. 2 : Interaction effects of varieties and planting dates on net photosynthetic rate at knee-high stage in rainy season maize (V1: PEEHM 5, V2: Pusa Composite 3, D1, D2 and D3 are the planting dates, July 9, July 24 and August 7, respectively)

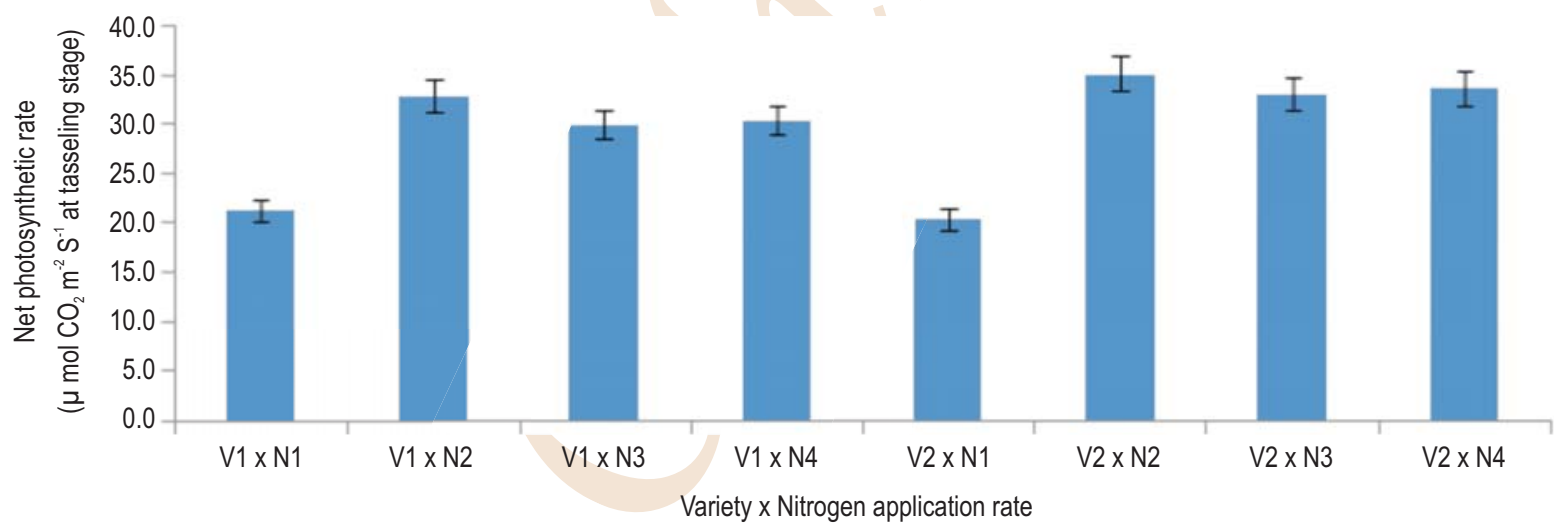

Fig. 3 : Interaction effects of varieties and nitrogen application rates on net photosynthetic rate at tasseling stage in rainy season maize (V1: PEEHM 5, V2: Pusa Composite 3; N1: Control (No-N application); N2: Chlorophyll meter based N application up to silking i.e. $30 \mathrm{~kg} \mathrm{ha}^{-1} \mathrm{~N}$ basal +30 kg ha- $\mathrm{N}$ top-dressed each time leaf SPAD value falls to $\leq 37.5$; N3: CMBSW: Chlorophyll meter based N application stage-wise i.e. $30 \mathrm{~kg} \mathrm{ha}^{-1} \mathrm{~N} \mathrm{basal}+30 \mathrm{~kg}^{-1} \mathrm{~N}^{-1}$ top-dressed each at knee high, pre-tasseling and silking stages when SPAD value falls to $\leq 37.5 ; \mathrm{N} 4$ : STCRB: Soil test crop response based N application) 


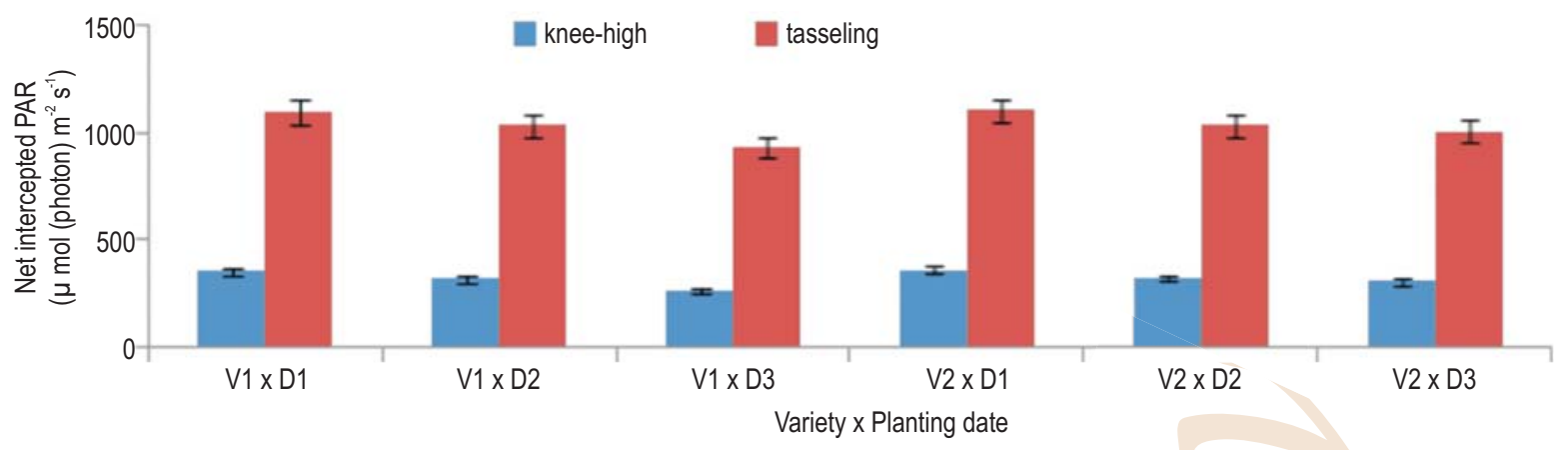

Fig. 4 : Interaction effects of variety and planting dates on net intercepted photosynthetically active radiation (PAR) in rainy season maize (V1: PEEHM 5 , V2: Pusa Composite 3, D1, D2 and D3 are the planting dates, July 9, July 24 and August 7, respectively)

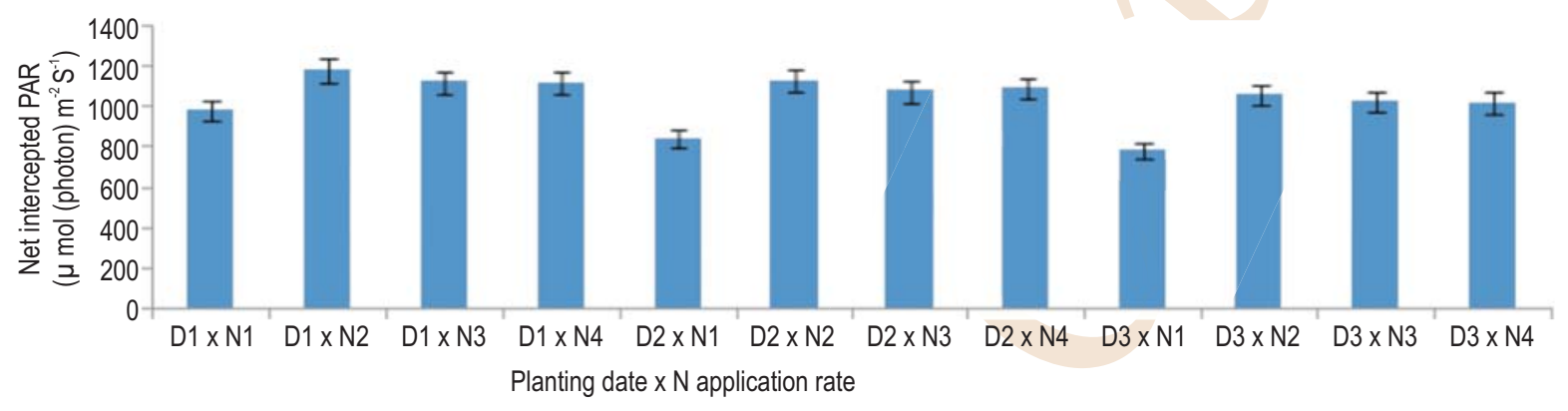

Fig. 5 : Interaction effects of varieties and planting dates on net photosynthetic rate at knee-high stage in rainy season maize (D1, D2 and D3 are the planting dates, July 9, July 24 and August 7, respectively; N1: Control (No-N application); N2: Chlorophyll meter based N application up to silking i.e. $30 \mathrm{~kg}$ ha"-1 N basal $+30 \mathrm{~kg}^{-1} \mathrm{~N}$ top-dressed each time leaf SPAD value falls to $\leq 37.5$; N3: CMBSW: Chlorophyll meter based $\mathrm{N}$ application stage-wise i.e., $30 \mathrm{~kg}$ ha-1 $\mathrm{N}$ basal $+30 \mathrm{~kg} \mathrm{ha}^{-1} \mathrm{~N}$ top-dressed each at knee high, pre-tasseling and silking stages when SPAD value falls to $\leq 37.5 ; \mathrm{N} 4$ : STCRB: Soil test crop response based N)

revealed that PEEHM 5 performed significantly better under earlier planting dates ( 9 and 24 July) and produced significantly inferior yields under late planting (7 August). Although grain yield in PC 3 also declined with delayed sowing, but the differences between 24 July and 7 August sowing were non-significant; yield reduction in $\mathrm{PC} 3$ consequent to late planting was not as severe as in PEEHM 5, likely due to higher leaf area, higher nutrient and water uptake due to greater root length and more efficient conversion of intercepted radiation into dry matter compared to PEEHM 5. Earlier planting (July 9, July 24) resulted in significantly higher amount of NPR, intercepted PAR, DMA in leaf, stem and root, yields (grain and straw) and harvest index across the varieties and nitrogen treatments in comparison to August 7 .

In the current study, July, 9, July 24 and August 7 sown plants were extended up to 11 October, 21 October and 2 November for PEEHM 5 and 27 October, 2 November 12 November, respectively for PC 3 . The average daily maximum and minimum temperature during the six crop durations (9 July - 11 October, 9 July - 27 October, 24 July - 21 October, 24 July - 2
November, 7 August - 2 November, 7 August - 12 November) were 35.3 and 25.0, 34.8 and 23.8, 34.5 and 23.7, 34.2 and 22.9, 34.2 and 22.4 and 33.8 and $21.6^{\circ} \mathrm{C}$, respectively. The average daily temperature for growth of maize was $32{ }^{\circ} \mathrm{C}$. Under delayed sowing, maize crop experienced comparatively lower average daily temperature resulting in low vegetative growth which might have reduced NPR. Similarly, the mean daily relative humidity and amount of rainfall was also considerably lower in later planting dates which might have caused moisture stress during the reproductive phase and consequently lower PAR, NPR, biomass production and yield in late planted crop (Riboldi et al., 2016) . These results reflect the findings of several past workers like Barutcular et al. (2005); Eliaspour et al. (2014), Almodares and Darany (2006), Azadbakht et al. (2012) who reported that earlier planting provides suitable conditions for utilization of agricultural inputs and longer growing duration in maize due to congenial weather parameters increasing biomass production and yield.

Like varieties and panting dates, effect of $\mathrm{N}$-application was also significant for physiological parameters, growth and 
yield of maize. The NPR and PAR were significantly higher when $\mathrm{N}$ was applied on the basis of SPAD value $\leq 37.5$ (CMB treatment) compared to other $\mathrm{N}$ treatments due to better growth of maize plants (Table 1) under regular supply of $\mathrm{N}$ maintaining higher SPAD values (chlorophyll content index) under this treatment. SPAD meter readings are fairly correlated with leaf greenness and $\mathrm{N}$ contents in plant (Rorie et al., 2011), and thus, can be used to estimate chlorophyll content (Hakim et al., 2015). At knee-high stage, $\mathrm{CMB}$ recorded $7.9 \mu \mathrm{mol} \mathrm{CO} \mathrm{C}^{-2} \mathrm{~s}^{-1}$ higher NPR over control and $3.1 \mu \mathrm{mol} \mathrm{CO}_{2} \mathrm{~m}^{-2} \mathrm{~s}^{-1}$ higher than STCRB N application. The corresponding increase in NPR due to CMB was 13.1 and 2.4 $\mu \mathrm{mol} \mathrm{CO} \mathrm{m}^{-2} \mathrm{~s}^{-1}$ at tasseling stage (Fig. 3, 5). Chlorophyll meter based (CMB) $\mathrm{N}$-application also resulted in higher biomass production at later growth stages (tasseling and maturity) finally leading to $9.25 \%$ higher grain yield and $7.65 \%$ higher straw yield. Thus, chlorophyll meter is an efficient tool for detecting locationspecific and timely $\mathrm{N}$-deficiency and schedule supply of readily available $\mathrm{N}$ to different crops (Xiong et al., 2015).

This study conclusively proved that maize hybrid variety PEEHM 5 will be useful for grain yield and biomass production under optimum planting condition, however in case of delayed planting, PC 3 could be better choice in the sandy loam soil of North Indian plains. Application of $\mathrm{N}$ should be scheduled on the basis of chlorophyll meter reading (average SPAD values $\leq 37.5$ ) for higher grain yield and saving of $10 \mathrm{~kg} \mathrm{~N} \mathrm{ha}^{-1}$.

\section{Acknowledgments}

Authors express their sincere gratitude to the Dean, Joint Director Research and Director, ICAR-Indian Agricultural Research Institute, New Delhi for providing technical guidance and financial support for this research. Authors thank Mr. Sanjeev Kumar (Technical Officer) for his help in conducting the field experiment and recording required observations.

\section{References}

Almodares, A., R.H. Hotjatabady and E. Mirniam: Effects of drought stress on biomass and carbohydrate contents of two sweet sorghum cultivars. J. Environ. Biol., 34, 585-589 (2013).

Almodares, A. and S.M. Mostafafi Darany: Effects of planting date and time of nitrogen application on yield and sugar content of sweet sorghum. J. Environ. Biol., 27, 601-605 (2006).

Anonymous: Using the LI-6400/LI-6400XT Portable Photosynthesis Systems-Instruction Manual, version 6, p. 1324 (2011).

Anonymous: Operator's Manual-AccuPAR PAR/LAI Ceptometer, Model LP-80, Decagon Devices, Inc., Pullman, Washington, USA(2015).

Azadbakht, A., G. Azadbakht, H. Nasrollahi and Z. Bitarafan: Evaluation of different planting dates effect on three maize hybrids in Koohdasht region of Iran. Int. J. Sci. Adv. Technol., 2, 34-38 (2012).

Barutcular, C., M. Koc, M. Unlu, R. Kanber, B. Ozekici, T. Yano and T.
Watanabe: Maize photosynthesis and productivity in relation to sowing time in a medeterranean environment, Cukurova. Asian J. PI. Sci., 4, 550-554 (2005).

Dass, A., A.K. Vyas and R. Kaur: Nitrogen management in precision farming by soil plant analysis development meter. Indian Farming, 63, 33-35(2014).

Dass, A., B.G. Shivkumar, S. Dhar and K. Kumar: Soil and plant based precision $\mathrm{N}$ management in rabi maize (Zea mays $\mathrm{L}$.) in northIndian alluvial plains. Ann. Agric. Res. New Series, 36, 358-363 (2015).

Economic Survey: Economic Survey. Directorate of Economics and Statistics, Department of Agriculture and Cooperation, GOI, A-19 (2014-2015).

Eliaspour, S., F. Shirzadi, F. Zandian and A. Gholami: The effect of plant date and density on growth index of maize variety (KSC 704) in tropical region of Kermanshah Province. Int. J. Agron. Agric. Res., 5, 93-102 (2014).

Enujeke, E.C.: Effects of variety and spacing on yield indices of openpollinated maize in Asaba area of Delta State. Sustain. Agric. Res., 2,1-11 (2013).

Faizan, S., S. Kausar and R. Parveen: Variation in growth, physiology and yield of four chickpea cultivars exposed to cadmium chloride. J. Environ. Biol., 33, 1137-1142 (2012).

FAO: Fertilizers and their use, Rome: FAO, International Industry Association, pp. 35-38 (2000).

Fox, R.H., W.P. Piekielek and K.M. Macneal: Comparison of late-season diagnostic test for predicting nitrogen status of corn. Agron. J., 93, 590-597 (2001)

Gomez, K.A. and A.A. Gomez: Statistical Procedures for Agricultural Research. John Wiley and Sons, Inc., International Rice Research Institute, Philipines, pp. 247-262 (1984).

Hakim, M.A., A.S. Juraimi, M.M. Hanafi, M.Y. Rafii, M.R. Ismail, S.M.R. Karim and $\mathrm{H}$. Kausar: Integration of herbicides with manual weeding for controlling the weeds in rice under saline environment. J. Environ. Biol., 36, 1311-1317 (2015).

Muurinen, S. and P. Peltonen-Sainio: Radiation-use efficiency of modern and old spring cereal cultivars and its response to nitrogen in northern growing conditions. Field Crops Res., 96, 363-373 (2006).

Riboldi, L.B., R.F. Oliveira and L.R. Angelocci: Leaf turgor pressure in maize plants under water stress. Aust. J. Crop Sci., 10, 878-886 (2016).

Rorie, R.L., L.C. Purcell, D.E. Karcher and C.A. King: The assessment of leaf nitrogen in corn from digital images. Crop Sci., 51, 2174-2180 (2011).

Singh, P., U.N. Shukla, K. Kumar, S. Singh, V. Kumar and R. Kumar: Evaluation of growth, yield and quality of maize as influenced by genotypes and nitrogen levels. Bangladesh J. Bot., 43, 59-64 (2014).

Tollenaar, M. and W. Migus: Dry matter accumulation in maize grown hydroponically under controlled-environment and field conditions. Can. J. Plant Sci., 64, 475-485 (1984).

Xiong, D., J. Chen, T. Yu, W. Gao, X. Ling, Y. Li, S. Peng and J. Huang: SPAD-based nitrogen estimation is impacted by environmental factors and crop leaf characteristics. Sci. Rep., 5, doi: 10.1038/ srep13389 (2015). 